\title{
SUSTAINABLE DEVELOPMENT GOALS: A BUSINESS OPPORTUNITY FOR TOURISM COMPANIES?
}

\author{
GiUlio PatTANARo, ${ }^{1}$ Silvia Donato ${ }^{2}$ \\ ${ }^{1}$ Independent researcher \\ e-mail: giuliopattanaro@gmail.com \\ ${ }^{2}$ Independent researcher \\ e-mail: silviadonato81@gmail.com
}

\begin{abstract}
\begin{tabular}{l|l} 
JEL CODES & M20, Z32, Z38
\end{tabular}
KEYWORDS sustainable tourism, Sustainable Development Goals, corporate sustainability

ABSTRACT $\quad$ The United Nations designated the year 2017 as the International Year of Sustainable Tourism for Development with the aim to underline the key contribution of tourism to achieve 17 Sustainable Development Goals (SDGs) of the 2030 Agenda for Sustainable Development. The paper looks at the business opportunities that the SDGs might generate for tourism companies. A literature review will be followed by an analysis of practical examples of implementation of the SDGs in the area of tourism, with a focus on private sector -led initiatives. Some conclusions on the SDGs-related business opportunities for tourism companies will be drawn and further research on the topic will be suggested.
\end{abstract}

\section{Introduction}

By designating 2017 as the International Year of Sustainable Tourism for Development, the United Nations General Assembly wanted to underline the key contribution of tourism to achieving the objectives of the 2030 Agenda for Sustainable Development and the 17 Sustainable Development Goals (SDGs) which were adopted in September 2015. 
The SDGs concern developed and less developed countries and address a wide range of socioeconomic and environmental challenges which are closely linked to tourism development. For instance, they encourage the adoption of sustainable consumption and production patterns (SDG 12).

The paper looks at the implementation of the SDGs in the tourism sector, with a focus on the business opportunities that their adoption might generate. A review of the most relevant literature on the subject in question is followed by the analysis and comparison of practical examples of the implementation of the SDGs in tourism companies.

\section{SDGs, private sector and tourism}

Being universally applicable, the 17 SDGs address the key priorities of today's economies, societies and the environment "as a network, in which links among goals exist through targets that refer to multiple goals" (Le Blanc, 2015, p. 1). In addition to tackling challenges like poverty and hunger which are not yet fully overcome in many parts of the world, the SDGs also specifically address new challenges like sustainable consumption and production.

In particular under SDG 17 (Strengthen the means of implementation and revitalize the Global Partnership for Sustainable Development), the 2030 Agenda highlights the key role that the private sector plays in implementing the SDGs and encourages "effective public, public-private and civil society partnerships, building on the experience and resourcing strategies of partnerships" (UN, 2015, 17.16).

Engaging private businesses in the SDGs may facilitate, among other things, the access to innovation capital and complementary expertise, as well as leverage public sector's funding for sustainable development with private sector investments (SDG Fund, 2016).

While underlining that the adoption of sustainable business practices by private companies is quite of a challenging process (Scheyvens, Banks, Hughes, 2016), academic literature points out the practical motives which are behind this process: for instance, the concern for image and reputation management or the willingness to improve relations with national governments, with sustainability adding value to brands (Pillai, Slutsky, Wolf, Duthler, Stever, 2017).

Efforts have also been put in identifying the most optimal standards and indicators to monitor, report and assess the transition towards sustainable business practices (for an overview, see Behringer, Szegedi, 2016; Garriga, Melé, 2004; Moon, 2007). The "SDG Compass", a dedicated tool for sustainability reporting in the context of the SDGs, has been made available (GRI, UN Global Compact \& WBCSD, 2015). While for large enterprises the cost of sustainability reporting may still be lower than costs for marketing or public relations, there is some concern that in the case of Small and Medium-sized Enterprises (SMEs) this cost could be a burden (GRI, 2013).

Coming more specifically to the area of tourism, the United Nations World Tourism Organization (UNWTO) strongly affirmed the great potential of tourism to contribute to the achievement of the SDGs and has set up partnerships with different actors (e.g., national governments, development banks, private actors, other UN agencies) in order to make this contribution happen (UNWTO, 2015). Particular emphasis has been put on the three SDGs where tourism is 
explicitly mentioned among specific targets - SDG 8 (Promote sustained, inclusive and sustainable economic growth, full and productive employment and decent work for all); SDG 12 (Ensure sustainable consumption and production patterns); and SDG 14 (Conserve and sustainably use the oceans, seas and marine resources for sustainable development) - but it has been stressed that the contribution of tourism to achieving the objectives of Agenda 2030 can go beyond these three SDGs and reach out to all the 17 goals. For example, tourism can contribute to poverty reduction (SDG 1) through job creation, support more sustainable and inclusive cities and human settlements (SDG 11), protect biodiversity and respect terrestrial ecosystems (SDG 15).

While underlining that tourism can be a major player among businesses contributing to the SDGs, academic literature has also pointed out some of the issues and challenges linked to the adoption of the SDGs by private tourism players: for instance, the difficulties in selecting which of the 17 SDGs to prioritise, in moving from concepts and principles to implementation and practice and in reporting progress in a standardised and certified way (Jones, Hillier, Comfort, 2007).

In order to encourage the uptake by tourism companies of the SDGs and, more in general, of sustainable tourism practices, some tools directly related to well-known managerial concepts such as corporate social responsibility (CSR) have been provided to encourage. This is the case, for example of Hughes and Scheyvens' (2016) Development First framework or de Grosbois' (2016) performance evaluation model of CSR in the cruise industry. Emerging concepts and models are also frequently referred to, like it is the case of Becken and Bobes' (2016) study making the case for carbon reporting in the travel and tourism industry.

\section{Method}

In order to assess if the adoption of the SDGs has a potential to create business opportunities for tourism companies, a search for examples of tourism businesses implementing the SDGs in their activities was performed. Given that no example of tourism companies was mentioned in two global reports (PwC, 2015; SDG Fund, 2016) on the implementation of SDGs by businesses, the search was performed in the UNWTO web portal dedicated to 2017 International Year of Sustainable Tourism for Development (UNWTO, 2017), where different tourism players (including private businesses) can share solutions, stories and knowledge in relation to embracing the SDGs in their daily activities.

This repository of solutions, stories and knowledge was carefully reviewed and analysed; the links and additional information reported under each entry were also explored and examined, in view of collecting and integrating further data and figures.

\section{A limited number of examples}

On 1 August 2017 - the last available date for gathering information available on the web portal and starting the analysis in preparation of the present paper - the UNWTO repository included 99 entries under solutions, 49 under stories and 37 under knowledge. While inputs from private actors represented almost one third of the entries under solutions (32 out of $99 ; 32.3 \%$ ), they were only 
marginally present under stories (8 out of 49; 16.3\%) and knowledge (5 out of 37 entries; 13.5\%). In the case of stories and knowledge, most inputs come from public bodies and NGOs or from multi-actor initiatives gathering public actors, civil society and the private sector. In terms of typology of private actors involved, while tour operators (web-based booking portals are included in this category) appear to be predominant in the case of solutions, under stories the majority (4 out of 8; $50 \%$ ) of private sector entries are related to the hospitality industry. Consultancy firms are the most represented private actors under knowledge.

With the exception of some firms which offer consultancy - and, sometimes, also certification - on all the aspects of sustainability, most of the entries from private actors focus on environmental sustainability (energy and water saving, preservation of biodiversity) or social sustainability (accessible tourism and interactions with the local community). This focus on a specific component of sustainability is common to most of the inputs, independently on the category of actors which is considered. For example, 40 out of 99 solutions (40.4\%) are related to environmental protection.

Figures in terms of beneficiaries, revenues or social impact (i.e. gender, education, etc.) are limited or not available. In a number of stories ( 9 out of 49 ; $18.4 \%$ ) business opportunities are related to the valorisation of local and sustainable food products or agricultural production systems.

In terms of geographical coverage, the entries included in the UNWTO repository cover different countries in all continents.

The SDGs are very frequently mentioned only in general terms in most entries and a reference to one (or more than one) specific SDG is very rare: only two entries mention a specific SDG and none of these entries comes from private actors. This is true also for those cases - like, for example, water-efficiency focused initiatives - where the association to a specific SDG - e.g., SDG 6 (Ensure availability and sustainable management of water and sanitation for all) - could be quite straightforward.

Specific tools and figures to measure and assess the achievement of the SDGs are also very rarely present: the information provided in the UNWTO repository and in the related links appears to be rather generic. No figures could be found on the economic impact (e.g., return on investment or impact on sales) resulting from the adoption of the SDGs in the daily activities of companies.

\section{A question still open}

As it was mentioned in the previous paragraphs, there is a general consensus on the business opportunities linked to the adoption of the SDGs by tourism players: among others, the creation of new markets, an increased competitiveness, and a positive reputation and image. Based on this, one might assume that many tourism operators have been already adopting the SDGs in their daily business.

Against this assumption, the research carried out in the context of this paper appears to show that the adoption of the SDGs in the tourism sector is either a very marginal phenomenon or it is something which is not adequately promoted and made visible, or a combination of both. In the UNWTO web portal dedicated to 2017 International Year of Sustainable Tourism for Development 
the number of initiatives put forward by the private sector is still rather limited. Furthermore, in the limited number of initiatives which are reported in the web portal, no specific data and figures on the business opportunities generated by the adoption of the SDGs could be found. This could also explain why no specific reference is made to specific SDGs in almost all the entries.

Different reasons might contribute to explaining what has been observed. Private tourism companies might still be quite unfamiliar with the SDGs and prefer to mention sustainability more in general. It might also be a matter of the limited, or perceived as limited, capacity of the SDGs to reach out to the general public and/or of some scepticism about the real business opportunities resulting from the adoption of the SDGs. Sustainability reporting might also be perceived by private companies, above all SMEs, as a rather costly and burdensome process.

From the analysis of the UNWTO web portal, it also emerges that public intervention is often needed to encourage the adoption of sustainability. Market drivers do not seem to be enough. A number of sustainable tourism initiatives in which the private sector is involved are indeed led or stimulated by the public sector. This is the case of regional or municipal initiatives (e.g., the region of Catalonia in Spain or the municipality of Chennai in India) planning sustainability-oriented actions or the case of specific projects funded by EU programmes (i.e. the Fisheries Local Action Groups supported under the European Maritime and Fisheries Fund).

The present research also appears to show that sustainability tends to be mentioned from the specific point of view of one of its three main components (environment, society and economic) rather than from an overall perspective. Environmental protection (with a focus on resource efficiency) and a concern for the social impacts of tourism (with a focus on the accessibility for all and on building links with the local community) appear as the most recurrent themes. In the same line, when sustainability is translated into SDGs, tourism players tend to mention a general support to the SDGs process, without selecting any specific SDG. A limited knowledge of the SDGs and/ or the preference to be generic in external communication might explain this. It might also be that some of the materials uploaded in the UNWTO web portal had been already developed before the adoption of the SDGs with an original emphasis on sustainability at a general level; this material was then most probably adjusted to the SDGs paradigm.

If the concept of sustainability tends to be interpreted in a rather narrow way, its universality appears to have been fully acknowledged and appreciated by tourism players. The current research shows that sustainability and the SDGs, as a growth model and business opportunity, apply equally to different social and economic realities, in both developed and developing countries. The connections between operators located in developed and less developed countries also highlight the truly global nature of tourism and recognise the importance of collaboration on equal footing.

\section{Limitations}

Further research on the business opportunities linked to the adoption of the SDGs by tourism companies is suggested. More examples should be examined and some specific case studies should be analysed in depth, perhaps via interviews and surveys. The analysis should also include 
a temporal dimension, to see if there is an evolution over time of the appreciation of the SDGs by private tourism operators.

\section{Conclusions}

The present paper wanted to analyse the business opportunities that the SDGs might generate for tourism companies.

Even if there seems to be a general consensus on the positive business impact of the adoption of the SDGs by tourism companies, the research which was carried out in the context of the present paper show that the adoption of the SDGs by tourism companies is still very limited. Furthermore, no clear figures in terms of business opportunities associated to such adoption - e.g., new markets, new products, better competitiveness, etc. - could be found. This is why, as a result of the research carried out, the link between the adoption of the SDGs by tourism players and the generation of new business opportunities is still not evident.

Different reasons - e.g., non-familiarity with the SDGs, limited marketing appeal or a more general scepticism about real business benefits of the SDGs - may contribute to explaining this situation.

\section{References}

Becken, S., Bobes, L. (2016). Proving the Case: Carbon Reporting in Travel and Tourism. Amadeus Research Reports. Retrieved from: http://www.amadeus.com/documents/reports/carbon-reporting-taveland-tourism.pdf (16.11.2017).

Behringer, K., Szegedi, K. (2016). The Role Of CSR In Achieving Sustainable Development-Theoretical Approach. European Scientific Journal, 12 (22), 10-25.

de Grosbois, D. (2016). Corporate social responsibility reporting in the cruise tourism industry: A performance evaluation using a new institutional theory based model. Journal of Sustainable Tourism, 2 (24), 245-269.

Garriga, E., Melé, D. (2004). Corporate social responsibility theories: Mapping the territory. Journal of business ethics, $1(53), 51-71$.

GRI (2013). Global Reporting Initiative. Cost and burden of reporting. Retrieved from: https://www.globalreporting.org/ resourcelibrary/Cost-and-burden-of-reporting.pdf (13.11.2017).

GRI, UN Global Compact \& WBCSD (2015). Global Reporting Initiative, United Nations Global Compact, and World Business Council for Sustainable Development. SDG Compass - The guide for business action on the SDGs. Retrieved from: https://sdgcompass.org/wp-content/uploads/2015/12/019104_SDG_Compass_Guide_2015.pdf (16.11.2017).

Hughes, E., Scheyvens, R. (2016). Corporate social responsibility in tourism post-2015: a Development First approach. Tourism Geographies, 5 (18), 469-482.

Jones, P., Hillier, D., Comfort, D. (2017). The Sustainable Development Goals and the Tourism and Hospitality Industry. Athens Journal of Tourism, March, 7-17.

Le Blanc, D. (2015). Towards integration at last? The Sustainable Development Goals as a network of targets. DESA Working Paper No. 141. Retrieved from: http://www.un.org/esa/desa/papers/2015/wp141_2015.pdf (18.11.2017).

Moon, J. (2007). The contribution of corporate social responsibility to sustainable development. Sustainable Development, 5 (15), 296-306.

Pillai, K.V., Slutsky, P., Wolf, K., Duthler, G., Stever, I. (2017). Companies’ Accountability in Sustainability: A Comparative Analysis of SDGs in Five Countries. In: J. Servaes (ed.), Sustainable Development Goals in the Asian Context (pp. 85-116). Singapore: Springer. 
PwC (2015). PricewaterhouseCoopers. Make it your business - Engaging with the Sustainable Development Goals. Retrieved from: https:/www.pwc.com/gx/en/sustainability/SDG/SDG\%20Research_FINAL.pdf (18.07.2017).

Scheyvens, R., Banks, G., Hughes, E. (2016). The private sector and the SDGs: The need to move beyond 'business as usual'. Sustainable Development, 6 (24), 371-382.

SDG Fund (2016). Sustainable Development Goals Fund. Universality and the SDGs: A Business Perspective. Retrieved from: http://www.sdgfund.org/sites/default/files/Report-Universality-and-the-SDGs.pdf (14.07.2017).

UN (2015). United Nations. Transforming our world: the 2030 Agenda for Sustainable Development - A/RES/70/1. Retrieved from: http://www.un.org/ga/search/view_doc.asp?symbol=A/RES/70/1\&Lang=E (10.07.2017).

UNWTO (2015). United Nations World Tourism Organization. Tourism and the Sustainable Development Goals. Retrieved from: https://www.e-unwto.org/doi/book/10.18111/9789284417254 (16.07.2017).

UNWTO (2017). United Nations World Tourism Organization. Webportal of the International Year of Sustainable Tourism for Development 2017. Retrieved from: http://www.tourism4development2017.org (1.08.2017).

\section{CELE ZRÓWNOWAŻONEGO ROZWOJU: NOWE MOŻLIWOŚCI DLA PRZEDSIĘBIORSTW TURYSTYCZNYCH?}

\section{SŁOWA KLUCZOWE STRESZCZENIE}

turystyka zrównoważona, cele zrównoważonego rozwoju, CRS

Organizacja Narodów Zjednoczonych wyznaczyła 2017 rok jako Międzynarodowy Rok Zrównoważonej Turystyki na rzecz Rozwoju, mając na celu podkreślenie kluczowego wkładu turystyki w osiągnięcie 17 celów zrównoważonego rozwoju [ang. Sustainable Development Goals (SDGs)] w programie działań na rzecz zrównoważonego rozwoju do roku 2030.

W niniejszym artykule przeanalizowano możliwości biznesowe, które SDG mogą generować dla firm turystycznych. Po przeglądzie literatury przedmiotu, przedstawiono praktyczne przykłady realizacji celów zrównoważonego rozwoju w dziedzinie turystyki, ze szczególnym uwzględnieniem inicjatyw sektora prywatnego oraz zaproponowano dalsze badania na ten temat. 